\title{
Patent Law and the Materiality of Inventions in the California Oil Industry: The Story of Halliburton v. Walker, 1935-1946
}

\author{
Gerardo Con Díaz (10)
}

This article examines a patenting conflict between the Halliburton Oil Well and Cementing Company and an independent inventor named Cranford Walker. It argues that Halliburton's effort to lower the barriers to entry into the oil well depth measurement industry facilitated the re-emergence of materiality as a pre-condition for the patent eligibility of inventive processes. In 1941, Walker sued Halliburton for infringement of three of his patents, and Halliburton responded with an aggressive defense aimed at invalidating them. Over the next five years, the courts handling this conflict adopted very narrow legal theories developed during the Second Industrial Revolution to assess the patent eligibility of inventions that involved mental stepsprocesses such as mathematical computations, which people can perform in their minds. The resulting legal precedent cleared the path for Halliburton's short-term industrial goals and continued to shape patent law for the rest of the century.

Keywords: patent law, oil industry, materiality, competition, technology, innovation

In 1941, as World War II increased the global demand for oil products, a self-employed engineer named Cranford Perry Walker filed a lawsuit against the Halliburton Oil Well and Cementing Company. Based in Los Angeles, Walker had developed and patented a new device called the Depthograph, which allowed engineers to detect obstructions and measure fluid and gas pressure inside an oil pipe. Halliburton, a rapidly growing oil services giant, had acquired the rights to a similar device called the Echo-Meter. Armed with a stronger market presence than Walker and his young firm, Halliburton had already launched an oil well analysis service resembling the one that Walker aimed to establish. Walker hoped to carve out a place for the Depthograph in a market he was unlikely to dominate, so he sued Halliburton for patent infringement and sparked a legal battle that would take them both to the Supreme Court.

Published online July 29, 2021

(c) The Author(s), 2021. Published by Cambridge University Press on behalf of the Business History Conference. All rights reserved. This is an Open Access article, distributed under the terms of the Creative Commons Attribution licence (https://creativecommons.org/licenses/by/4.0/), which permits unrestricted re-use, distribution, and reproduction in any medium, provided the original work is properly cited. 
The story of Halliburton v. Walker, as this conflict is often cited, invites the study of intellectual property (IP) law to inquire into the history of the oil industry. In recent years, systematic attention to patents and copyrights has enabled scholars to revise and enrich the histories of several industries-from biotechnology and pharmaceuticals, to transportation, telecommunications, and software. ${ }^{1}$ Often firmly grounded on business history, their work has demonstrated how legal doctrine and practice have been inseparable from each industry's rapidly changing dynamics, generating new ways of placing technological and commercial development within their broader legal and regulatory contexts. This line of inquiry is especially compatible with the history of American oil, wherein the sociolegal and political frameworks that have governed the industry at the local and transnational levels have long been central themes. ${ }^{2}$ However, the oil industry is noticeably absent from the historiography of intellectual property, even though protections such as patents and trade secrets determine who can claim ownership over key technologies such as drills, pumps, and refinement techniques.

Accounting for Halliburton v. Walker is a valuable first step to correct this oversight, because the conflict shows how an independent inventor's efforts to enter the California oil industry transformed U.S. patent-eligibility standards by prompting courts to assess the legal merits and limitations of a rationale called the "mental steps doctrine." 3 This doctrine comprises the notion that procedures such as basic arithmetic computations, which properly trained people can perform in their minds, are ineligible for patent protection. Grounded on a series of opinions that date back to the nineteenth century, this doctrine is a key judicial exception to patent eligibility, alongside bans on patenting natural laws, abstract ideas, and products of nature. Judges, lawyers, and scholars have continually negotiated its meaning and limits, offering nuanced analyses of the conditions under which inventions involving mental steps qualify as the kinds of invention for which American patent law offers protection.

This article argues that Halliburton's effort to lower the barriers to entry into the oil well depth measurement industry facilitated the re-emergence of materiality as a precondition for the patent eligibility of inventive processes. ${ }^{4}$ It is divided into three parts. The first recounts how Walker

1. See, for instance, Parthasarathy, Patent Politics; Beauchamp, Invented by Law; Gabriel, Medical Monopoly; Fisk, Working Knowledge; Greene, Generic; Usselman, Regulating Railroad Innovation; Kevles, "Ananda Chakrabarty Wins a Patent."

2. See, for instance, Atabaki, Bini, and Ehsani, Working for Oil; Mitchell, Carbon Democracy; Sabin, Crude Politics.

3. The term "patent eligible" refers to inventions that fall within the scope of patent protection delineated by the Patent Act, codified in 35 U.S.C. Specifically, section 101 of the act establishes that an invention must be a "new and useful process, machine, manufacture, or composition of matter, or any new and useful improvement thereof" to be eligible for patent protection. This text has remained relatively unchanged for decades, though of course its meaning, applicability, and limitations have changed over time thanks to the accumulation of court opinions and procedures at the Patent Office and its successor, the Patent and Trademark Office. 35 USC §101.

4. A note on sources: The primary sources on which this article is grounded comprise a diverse collection documents archived by the courts that considered this case, including depositions, an assortment of sworn statements, trade literature, correspondence, advertisements, and periodicals. As a result, the historical interpretation of these records poses a challenge common in legal scholarship: generating historical narratives based on documents that opposing parties submitted, and which were often intended to deliver a story that would cause the court to rule a certain way. I generally only cite one document in cases when the facts on which I am relying are both uncontested by all parties and compatible with the general historical context I was able to reconstruct from the body of primary sources available for research and with the broader interpretive frameworks found in the scholarly literature. The main text will indicate when this was not possible by introducing 
launched his lawsuit against Halliburton. The two parties were trying to enter California's emerging market for oil well depth measurement services. Both had access to inventions that performed the same functions, though Walker had developed his independently, and Halliburton had secured its own through its corporate acquisitions strategy. The second part details the body of nineteenth-century law that shaped how judges at the district and appeals courts assessed, and ultimately invalidated, the patents that Walker had obtained. Halliburton's victory over Walker was made possible by the courts' embrace of nineteenth-century conceptions of a process that enshrined a patent's text as the ultimate proxy for the materiality of an invention. These conceptions, which required processes to cause changes in tangible substances in order to be eligible for patent protection, introduced the mental steps doctrine as a new way of engaging with century-old precedent in postwar American patent law. The third sketches the long-term impact that this conflict had on American patent law. As the country neared passage of a new patent act, courts adopted the Halliburton opinions as a new standard for the assessment of an invention's patent eligibility. This new standard became so deeply embedded in the patent system that courts would continue to draw from it for the rest of the century.

\section{Oil Wells and Echo Detection}

American oil firms became especially interested in California's petroleum in the $1930 \mathrm{~s} .{ }^{5}$ Oil deposits underneath cities such as Los Angeles, Santa Barbara, and Ventura had become popular prospective sites for extensive drilling. ${ }^{6}$ A 1929 decision by the California Supreme Court, Boone v. Kingsbury, required the state government to issue drilling permits, thereby enabling firms to set up wells across the state. ${ }^{7}$ Taxpayers and legislators alike soon started to protest the establishment of coastal wells on environmental grounds, so firms sometimes used slanted off-shore oil wells to access seaside deposits without drilling on state land. ${ }^{8}$ For the next decade, California remained among the most active regions in the production of crude oil, second only to the midcontinental region (which included portions of southern states such as Texas, New Mexico, and Oklahoma). ${ }^{9}$

Early fluctuations in the growth and productivity of the national oil industry in the 1930s motivated firms and independent researchers to develop more refined drilling and well-prospecting technologies. Among the independent researchers was Cranford P. Walker, an engineer with expertise in transportation, electricity, and fluids. ${ }^{10}$ Walker had spent most of his career in Los Angeles, first with the Westinghouse Company and then with the Llewellyn Iron Works

my observations as possibilities or plausible circumstances or noting that no further sources were available for research. This is especially important in the sections that deal with industry secrets, Walker's motivations, and Halliburton's overall strategy.

5. Sabin, Crude Politics, 55.

6. Ibid., 54-56.

7. Ibid., 56-67.

8. Ibid., 73-78.

9. Williamson et al., "The American Petroleum Industry”; Andreano, Daum, and Klose, The American Petroleum Industry.

10. Deposition of Cranford P. Walker, Transcript of record, Halliburton v. Walker (hereafter ToR), 154-155. 
Company, a prominent metal product company that would later become the Consolidated Steel Corporation. While working at Llewellyn, he and his colleagues had secured four patents-two for elevator technologies and one each for a motorized voltage control system and a valve operating mechanism. ${ }^{11}$ In 1935, after his employment with Consolidated Steel ended, he became a consulting electrical and mechanical engineer to firms in Southern California.

That year, while looking for consulting work, Walker attended an equipment demonstration at the Shell Corporation's research laboratory in Ventura, California. ${ }^{12}$ Unlike firms like Standard Oil, which had been operating in the United States since the nineteenth century, Shell was a relative newcomer to the American oil industry. ${ }^{13}$ It had arrived at the United States on the eve of First World War I while operating as Royal Dutch/Shell, and it had expanded its operations to include subsidiaries in California and the midcontinent. The Depression had taken a toll on its operations, as the company's expensive lands and high operating costs became increasingly harder to maintain. ${ }^{14}$ Equipment demonstrations enabled Shell to show it had the technological means to remain competitive despite the economic downturn, so the company used them to create important first points of contact with potential licensees for the technologies developed by its research and development scientists.

The 1935 demonstration featured work by two of Shell's engineers, Paul Lehr and Harold Wyatt. ${ }^{15}$ The two inventors had developed a new way of measuring and controlling a well's oil output. A central problem in this field was determining just how deep inside the well one would find the surface of the oil pool. ${ }^{16}$ Over the years, industry engineers had developed several techniques to perform these measurements, but none of them were accurate enough to be reliable. These techniques ranged from the use of weighted ropes that could be lowered into the wells, to intricate systems of revolvers, tuning forks, and pen arms that recorded the time it took for sounds to travel across the tubes. ${ }^{17}$

Wyatt and Lehr's event was Shell's response to a popular industry rumor at the time, according to which a Los Angeles-based company called Union Oil had developed an automatic electric system that measured the depths of oil wells using sound waves. ${ }^{18}$ This rumor left behind a very sparse paper trail, but court records make two things clear about it. First, like Shell, Union Oil was very interested in determining oil well capacity and had developed a strong interest in pool depth measurement. Second, for at least two years, Union's scientists had been testing different sound-based depth measurement devices across California, but the extent of their success in the matter remained a secret to outsiders. ${ }^{19}$

Perhaps in response to this secrecy, the Shell engineers aimed to show that their company was working on this problem as well and to give their small audience a taste of their work. The

11. Lyons and Cranford, Elevator door operator; De Camp, Baruch, and Walker, Automatic stopping elevator control system; Bouton and Walker, Variable-voltage-control system; Walker, Valve operating means.

12. Deposition of Cranford P. Walker, ToR, 154-155.

13. Priest, The Offshore Imperative, 12-17.

14. Ibid., 15.

15. Deposition of Harold T. Wyatt, ToR, 244; deposition of Paul Lehr, ToR, 262.

16. ToR, 245 .

17. Rodd, “The Application of Fluid Level Measurements to Oil Wells in Kansas”; Batcheller, Apparatus for locating obstructions in tubes.

18. Testimony of Harold Wyatt, ToR, 246-247.

19. Testimony of Howard C. Pyle, ToR, 490-493. 
whole event was, according to Walker, a "crude home-made affair." ${ }^{20}$ It began when Wyatt placed his hand over the well. Lehr then shot a puff of air into the well, and Wyatt measured the time between Lehr's shot and the moment when he either felt a puff of air on his hand or heard the shot's echo coming from inside the well-whichever came first. From this measurement, the two engineers computed how deep inside the well the pool of oil was located. ${ }^{21}$

Lehr and Wyatt illustrated the general principle that they had employed without revealing the technical specifications of their invention. They explained that they had filed a patent application for their invention and showed the audience the equipment that performed the measurements, but they did not discuss exactly how their invention worked. ${ }^{22}$ Their actual invention, which would receive its patent in 1936 (Figure 1), resembled the one that the industry rumor had attributed to Union Oil. ${ }^{23}$ It used a pressurized gas chamber to generate the initial puff and a microphone attached to a pen needle to sense the echo. This enabled the user to create a graph depicting both the sound generated by the original shot and its echo. From this graph, the user could perform a few quick computations to estimate the depth of the well at which liquid would be found, but these computations fell outside the scope of the patent. ${ }^{24}$ This method was useful in the measurement of the depth of an oil pool and in the identification of any obstructions along the pipe from which the sound wave could bounce.

Unaware of the details of Lehr and Wyatt's invention, Walker left the demonstration with the goal of finding his own way of automating the process that the Shell engineers had shown. ${ }^{25} \mathrm{He}$ had become especially well acquainted with microphone technology while working at Westinghouse and Llewellyn, as it had allowed him to test the speed and acceleration of elevators. He therefore suspected that he could draw on his expertise with sound equipment to develop a high-quality system of his own. Perhaps, he reasoned, the systems that he had implemented to determine the length of elevator shafts could be adapted to the study of oil wells. ${ }^{26} \mathrm{He}$ also doubted that Wyatt and Lehr's patented method would yield accurate results. Oil wells were so deep that the air pressure at the bottom of the well could be significantly higher than the pressure at the well's opening. This meant that the speed at which the puff of gas and the echoes it generated traveled across the shaft were not constants, as Wyatt, Lehr, and several inventors before them seemed to assume. For this reason, Walker decided to transform the microphone system that he used in elevators into one that could be used in oil wells to detect echoes. He conferred with Wyatt and Lehr, and one month later he had created a system of his own, the Depthograph. ${ }^{27}$

In 1937, Walker submitted three patent applications: one for the device, one for its use to measure the location of obstructions, and one for a modification that allowed the measurement

20. Deposition of Cranford P. Walker, ToR, 155.

21. Ibid.

22. Deposition of Cranford P. Walker, ToR, 156.

23. Lehr and Wyatt, Method and apparatus for measuring well depths.

24. Ibid.

25. Deposition of Cranford P. Walker, ToR, 155-157.

26. Ibid.

27. Ibid., 157-158; S. Ct. 6. 
July 21, 1936. P. E. LEHR ET AL $\quad 2,047,974$

METHOD AND APPARATUS FOR MEASURING WELL DEPTHS

Filed Nov. 1, 1933

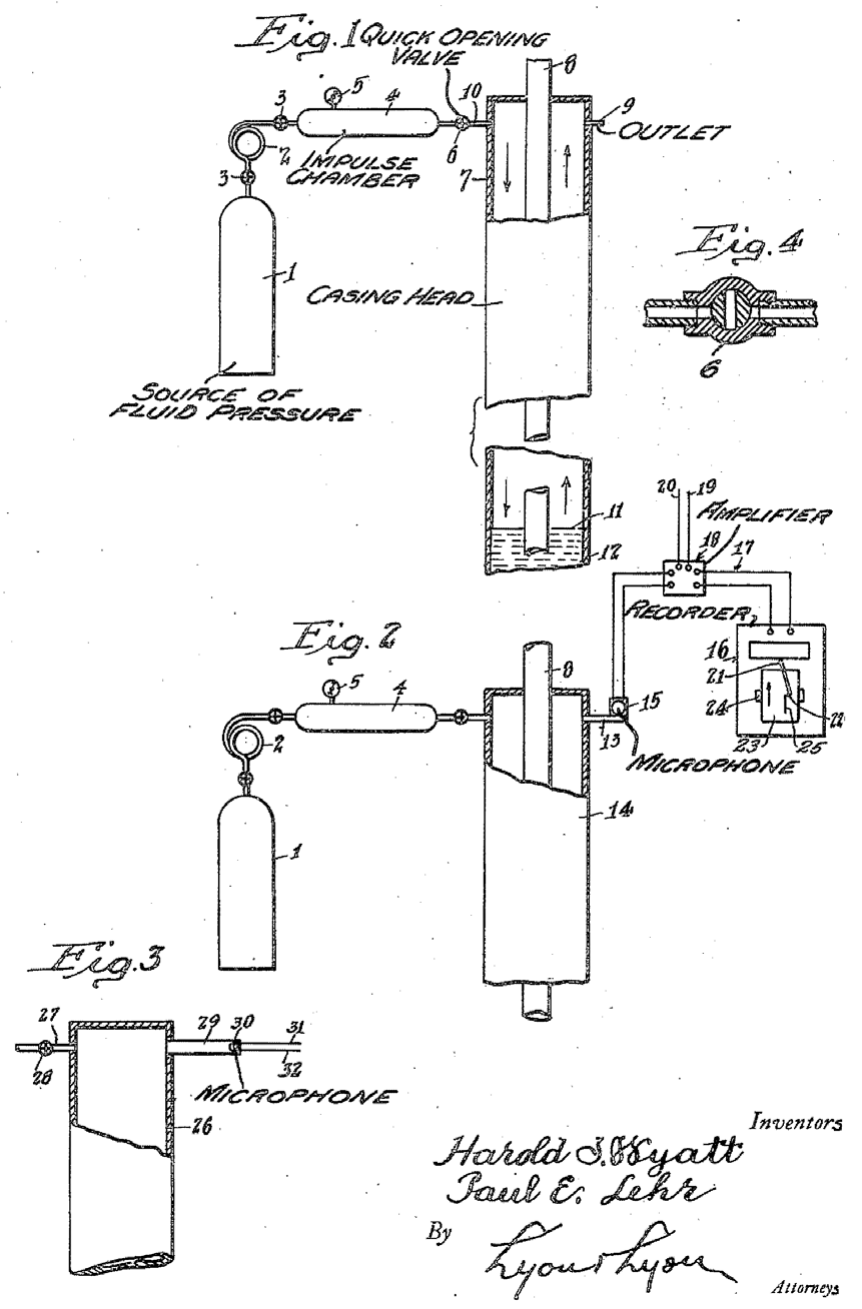

Figure 1 Schematic representations of an apparatus that Lehr and Wyatt used to measure the depth of oil wells and detect obstructions therein. Note the presence of a microphone and a pressurized gas chamber. Source: Walker, '974 patent.

of fluid density. ${ }^{28}$ Taken together, the three patents covered the Depthograph itself and two methods to perform what Lehr and Wyatt had demonstrated, citing their work as prior art. Figure 2 shows Walker's system. It relied on the observation that the sound that a blast of air

28. Walker, Means for measuring the location of obstructions in deep wells; Walker, Method of determining fluid density, fluid pressure, and the production capacity of oil wells; Walker, Method of measuring location of obstructions in deep wells. 
May 2, $1939 . \quad$ C. P. WALKER $2,156,519$

MEANS FOR MEASURING THE LOCATION OF OBSTRUCTIONS IN WELL̀S

Filed Sept. 7, 1937

2 Sheets-Sheet 1

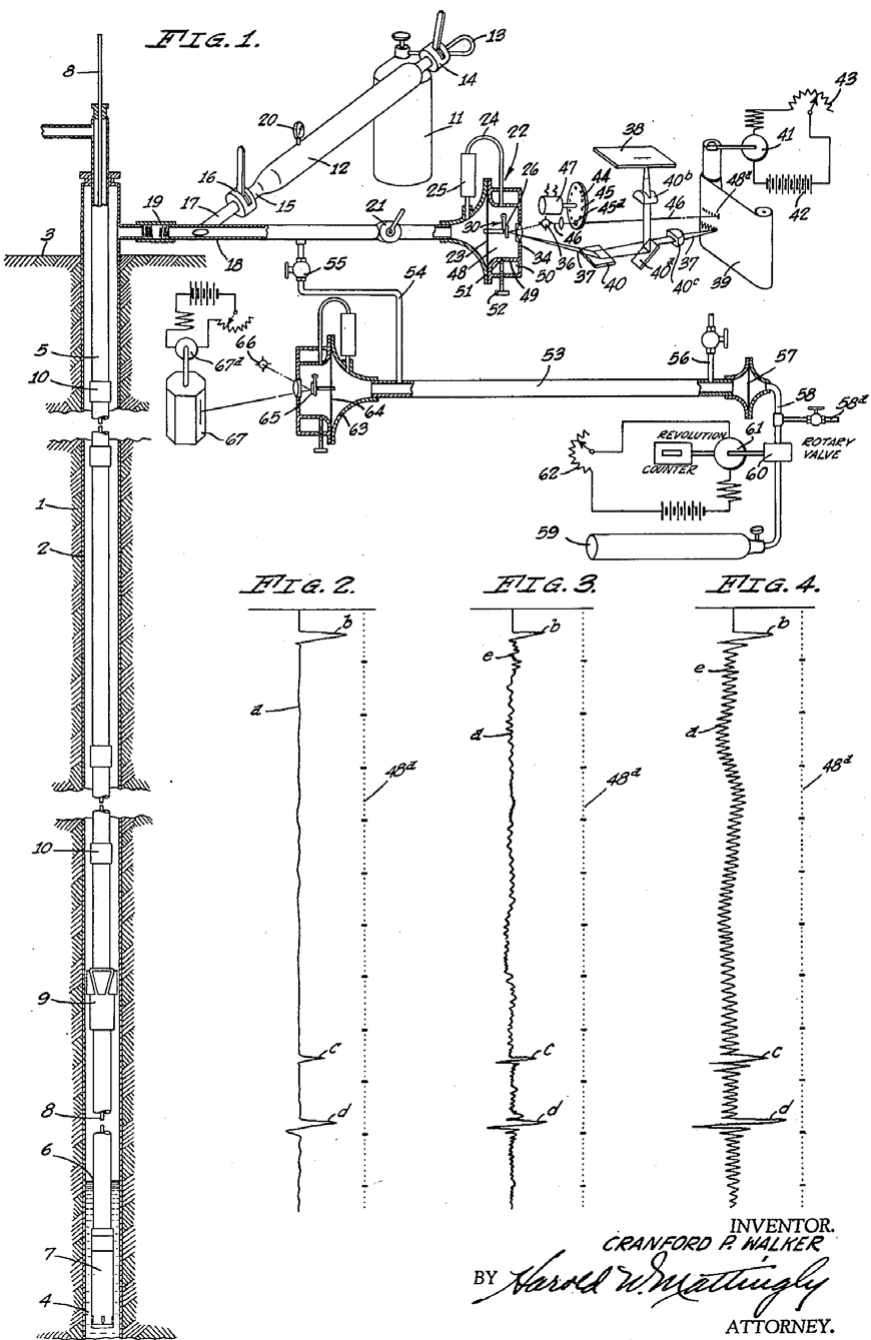

Figure 2 Walker's apparatus for the measurement of oil pool depth and detection of obstructions. The presence of tubing collars (such as those shown on the vertical pipe in the left-hand side of the image) caused sound waves to bounce back, producing the graphs on the bottom right-hand side. From these graphs and any supporting documentation available for the pipes, an engineer would be able to detect any unknown obstructions and determine how deep inside the well the pool of oil was found.

Source: Walker, '519 patent.

generated would bounce off not just from whatever liquid was at the bottom of the well, but also from structures such as pipe joints and blockages, which partially blocked the path of the sound. Walker set up a microphone and an acoustic resonator that amplified certain sounds, and a pen arm would create a single graph depicting every echo. It was then up to the user to 
distinguish the echoes generated by the surface of the liquid and any foreign objects inside the pipes from those generated by the known structures inside the well. The user could do this by comparing the new graph to one produced when the well was brand-new and unobstructed, or by examining a blueprint of the well and deciding which of the recorded echoes did not correspond to known structures. ${ }^{29}$

Walker was eager to transform his interest in well depth measurement into a new line of work. Soon after Wyatt and Lehr's demonstration, he and some of his colleagues founded the Depthograph Company, a firm meant to leverage whatever inventions Walker produced into a well-measurement and analysis service. ${ }^{30}$ Walker visited Shell to compare earlier versions of his equipment against Lehr and Wyatt's creations, and he started testing his final version of the Depthograph at real oil wells around the time he submitted his patent applications. ${ }^{31}$ The Depthograph Company eventually licensed Wyatt and Lehr's patent, and it became the sole assignee of Walker's patents once they were issued in 1939 and 1940. This allowed it to offer a range of measurement services and to bypass the technical limitations of Lehr and Wyatt's method without coming into conflict with Shell's lawyers.

Walker's growing relationship with Shell and his independent work on a problem as important as oil well measurement and analysis brought him into conflict with other firms in the petroleum services industry. Chief among them was the Halliburton Oil Well and Cementing Company. Just over ten years old, Halliburton was growing at an unprecedented rate, as the rapid creation of oil rigs across the United States had placed the firm's cementing services in high demand. With more than five hundred employees and one hundred cementing trucks, the firm relied on a series of proprietary inventions to provide unmatched speed in both drilling oil wells and lining them with cement. ${ }^{32}$ By the 1940 s, Halliburton also offered a well depth-measuring service. ${ }^{33}$ At the center of this service was a device called the EchoMeter, an automatic instrument that allowed users to locate both the fluid level within the well and any other obstructions therein. ${ }^{34}$

Halliburton had obtained the Echo-Meter through its corporate acquisitions and not its internal research and development. ${ }^{35}$ Back in the mid-1930s, when Shell sponsored Lehr and Wyatt's demonstration, Halliburton had launched its own investigation into the industry rumor about Union Oil's work on depth-measuring systems. Halliburton found that Union had, indeed, asked a mechanical engineer named John Jakosky to develop one such system. In 1937, around the time when Walker completed his invention, Jakosky had succeeded as well. He called the device the Echo-Meter, secured several patents covering it and several

29. Walker, Method for measuring the location of obstructions in deep wells.

30. The rest of this paragraph is based on Bill of Complaint, Halliburton v. Walker, ToR, 4-5; Rodd, "The Application of Fluid Level Measurements to Oil Wells in Kansas," 3-5.

31. Graphs made by Walker, ToR, 772, 775-779.

32. Briody, The Halliburton Agenda, 67-69.

33. Brief on rehearing for Cranford P. Walker, ToR, 20.

34. Halliburton ECHO-METER, in ToR, 621.

35. This paragraph is based on Brief for Halliburton Oil Well Cementing Company, Petitioner, Halliburton v. Walker, 329 U.S. 1 (1946): 17-25. 
modifications, and created a small company called International Geophysics around it. ${ }^{36}$ Halliburton purchased the company in 1940, thereby obtaining the rights to the Echo-Meter.

Jakosky and Walker had developed their inventions independently from one another, and it is unlikely that either one of them purposely copied the other one's work. Still, the Echo-Meter was very similar to Walker's invention. Both devices were designed to detect the depth of the well's liquid bottom, and they both relied on the use of a microphone and a pen arm to record the echoes produced by a sudden burst of sound. ${ }^{37}$ The two devices also required users to interpret the pen-arm's graph based on their knowledge of the internal structure of the piping, but they were substantially different in the components they comprised: the Echo-Meter used a gun (as opposed to a pressurized gas chamber) to create the initial explosion, and its sound recording system was very different from the Depthograph's. Despite their similarities, the Echo-Meter fell short of the Depthograph in several important aspects, especially the detection of small preexisting internal pipe structures and the calculation of other factors that affected oil production, such as fluid pressure. ${ }^{38}$

In 1941, Walker's Depthograph Company sued Halliburton for patent infringement at the District Court for the Southern District of California, the region where the alleged infringements had taken place. Depthograph's attorneys, Harold Mattingly and Robert Fulwider, complained that Halliburton was infringing Walker's three patents by "making, selling, leasing, and using apparatus for measuring the location of obstructions in wells and by practicing the methods of measuring location of obstructions in deep wells." ${ }^{39}$ In response, Halliburton's lawyers, Frank Graham and Earl Babcock, launched a number of defenses ranging from arguing that Walker was concealing information regarding his inventions' novelty to attacking the validity of the patents themselves. According to Halliburton, everything-from Walker's public demonstrations of his invention to his device's reliance on the prior art and the patent's disclosure of the invention-showed that the three patents at hand had not been "duly and legally issued." 40

Presiding over the trial was Peirson M. Hall, one of the court's newest judges. A former member of the Los Angeles City Council, Hall was best known for his expertise in matters relating to water, aviation, transportation, and the military. ${ }^{41}$ For the most part, Hall dismissed Halliburton's arguments against the validity of Walker's patents based on expert testimony delivered by witnesses (engineers and outside consultants including Lehr, Wyatt, and Walker) representing all the firms involved. Following their lead, Hall concluded that Walker's patents covered improvements on the available "means and methods for measuring the location of obstructions." 42 He found that the Echo-Meter infringed two of Walker's patents, because several of its components were functional equivalents to those found in the Depthograph. Halliburton's electrical sound filters were equivalent to Depthograph's acoustic resonators, and the methods that Halliburton was using to determine fluid pressure (including where to

36. Jakosky, Method and apparatus for continuous exploration of bore holes.

37. Plaintiff's Exhibit No. 6, ToR, 623.

38. Rodd, "The Application of Fluid Level Measurements to Oil Wells in Kansas," 6.

39. Bill of Complaint, ToR, 3.

40. Amended Answer of Defendant, ToR, 11.

41. Correspondence, 1940-1942, box 1, folder 13, Peirson M. Hall Papers.

42. Findings of Fact, April 22, 1943, ToR, 28-32. 
perform measurements and how to compute estimates) were equivalent to the ones that Walker had developed. In this sense, his ruling hinged on something called the doctrine of equivalents (the notion that courts can find patent infringement even when the infringing device is not identical to the device that the patent outlines). ${ }^{43}$

However, Hall also invalidated one of Walker's patents by noting that the invention was unpatentable under the Patent Act of 1870, which continued to be the law of the land. The act indicated that an invention must be a "new and useful art, machine, manufactures, or composition of matter, or any new and useful improvement thereof" to be eligible for a patent. ${ }^{44}$ This provision was continually applied and interpreted by courts at all levels during the Second Industrial Revolution. It had provided the backbone for patent protection during the rise and nationwide spread of new technologies and research infrastructures-from mass production and industrial research laboratories, to electrification and transcontinental railroading. ${ }^{45}$ More important was the fact that the common law that had developed around it had relied, often explicitly, on assuming that inventions involve the manipulation of tangible things. This body of law, to which this essay now turns, ultimately prompted Hall to rule that even the presence of a computation in a patent application was reason to doubt the invention's patent eligibility.

\section{The Materiality of Inventive Processes}

One of the most important features of in the rise of modern patent law was its increasing focus on the text of a patent as a stand-in for an invention. ${ }^{46}$ Early modern privilege-based patent regimes generally construed models (small-scale versions of an invention) to be proxies for the invention itself. In the eighteenth century, however, patent systems in countries such as France and the United States started to require inventors to submit a specification, namely a written description of the invention that would be made public so that other skilled people could replicate the invention. ${ }^{47}$ This enabled the legal separation between what one recent scholar called the "actual material invention" and the idea behind it. ${ }^{48}$ In turn, this transformed the material invention - the entity that would have been the subject of a royal privilege in the early modern period-into an embodiment of a textually defined invention. By the end of the nineteenth century, the details of patent texts were well on their way to replacing actual inventions and small-scale models as the main objects of analysis in American patent law.

One of the changes that accompanied this separation between material inventions and their textual descriptions was an increasing focus on pinpointing what constitutes a process and

43. For doctrinal analysis of this doctrine that includes a brief historical overview, see Graver Tank v. Linde Air Products, 339 U.S. 605 (1950).

44. Section 24, Patent Act of 1870.

45. Key works on this history include Fisk, Working Knowledge; Usselman, Regulating Railroad Innovation; Khan, The Democratization of Invention; Pottage and Sherman, Figures of Invention.

46. This paragraph is based on Biagioli, "Patent Republic." See also Pottage and Sherman, Figures of Invention.

47. See Rankin, "The 'Person Skilled in the Art' Is Really Quite Conventional."

48. Biagioli, "Patent Republic," 1143. 
characterizing it as a form of invention. This is a problem that British courts had been considering since the late eighteenth century, when James Watt secured a patent for a steam engine condenser separate from the engine itself. ${ }^{49}$ Watt might have attempted to patent the invention as a manufacture, but he feared that doing so would allow competitors to bypass his patent rights simply by making small changes to his device. Instead, one scholar has shown how the patent's presentation of the condenser "in much broader terms, as a method of conserving fuel by condensing steam in a separate chamber" prompted British courts and reporters to articulate an expansive definition of manufacture that encompassed certain kinds of processes. ${ }^{50} \mathrm{~A}$ treatise writer in 1818 explained that "the term manufacture is of most extensive meaning, and applies not only to things made, but to the practice of making; to principles carried into practice in a new manner; and to new results of principles carried into practice." 51

Back in the United States, in the absence of this broad definition of the term "manufacture," patent drafters' word choices and descriptive techniques became crucial evidence in courts' assessments of a process's patent eligibility. Inventions could only be patented when their textual description disclosed their embodiment in something material, so a few deep problems became recurring issues in patent law: determining what kinds of processes are embodiable and patent eligible, crafting a legal definition for "process," and helping patent examiners and judges determine when a textual description of a process does not correspond to a material invention. Courts found these problems especially difficult, because some processes-from Watt's condenser to Samuel Morse's telegraph communication system in the nineteenth century and software in the twentieth—could blur the legally constructed distinctions among inventions, ideas, and principles that stand at the core of IP law. ${ }^{52}$

Prior to the passage of the Patent Act of 1870, the Supreme Court ruled twice on the matter. First, in Corning v. Burden (1853), the court had provided a two-prong characterization of processes. ${ }^{53}$ On the one hand, the term "process" could refer to "the means or method of producing a result that is patentable," including "all methods or means which are not effected by mechanism or mechanical [combinations]." ${ }^{54}$ On the other hand, the term could be "used subjectively or passively as applied to the material operated on" and not to the specific method of producing that operation. Second, in Burr v. Duryee (1864), the court explained that a machine is "a concrete thing, consisting of parts, or of certain devices and combination of devices." 55 Each machine has a "principle" or "mode of operation"- the combination of devices that makes this machine different from others. Machines, were, of course, patent

49. This paragraph is grounded in Bottomley, The British Patent System During the Industrial Revolution, 1700-1852.

50. The word "method" is more appropriate than "process" for the British context, but the distinctions between the two were blurred in nineteenth-century U.S. cases. Ibid., 151.

51. Holt, Reports of Cases Ruled and Determined at Nisi Prius in the Court of Common Pleas, 62, cited in Bottomley, The British Patent System During the Industrial Revolution, 154.

52. This blurring among key categories in IP law occurred in copyright law as well. See Con Díaz, "Encoding Music”; Con Díaz, Software Rights; Samuelson, “The Story of Baker v. Selden.” For more on Morse, see Mossoff, "O’Reilly v. Morse.”

53. Corning v. Burden, 56 U.S. 252 (1853).

54. Ibid., at 268 .

55. Burr v. Duryee, 68 U.S. 531 (1864), 570. 
eligible, and infringement could be determined by assessing whether one machine embodied the same principle as another.

Perhaps the most important Supreme Court opinion on this matter was Cochrane v. Deener (1876), on the patent eligibility of a flour-making process created by an Ohio-based inventor named William Cochrane. This process involved passing the flour through a series of vibrating filters to sift out any large pieces of wheat meal, grinding these pieces, and repeating these two steps until the wheat meal was as fine as the rest of the flour. Cochrane and his colleagues had sued a flour-making firm called Deener, Cissel \& Welch for infringement of several patents covering this method. ${ }^{56}$ In response, the firm defended itself by arguing that Cochrane's patents claimed no devices whatsoever and that the patents were therefore invalid on the grounds that the inventions they disclosed were not new. ${ }^{57}$

The Burden and Duryee opinions formed the basis for the court's rejection of Deener's arguments. Justice Joseph Bradley, who had delivered the Duryee decision, explained that a process is "a mode of treatment of certain materials to produce a given result." In other words, it is "an act, or a series of acts, performed upon the subject-matter to be transformed and reduced to a different state or thing." ${ }^{58} \mathrm{He}$ also explained that processes are independent from, and just as patent eligible as, any machine. In fact, a process could be found to be patent eligible regardless of the "particular form of the instrumentalities used" in executing it. Cochrane did not confine his patent to any particular machine, so it was irrelevant whether the instrument or machine to make this powder was as common and well-known as "a hammer, a pestle and mortar, or a mill" 59

Bradley refined the Cochrane framework once again in $1881 .{ }^{60}$ Prompted by another infringement suit, Tilghman v. Proctor, he explained that a machine is "a thing," something that is visual to the eye and is therefore "an object of perpetual observation." In contrast, a process "is an act, or a mode of acting"-a "conception of the mind" that can be seen only by the effects that it produces when it is performed. ${ }^{61}$ Processes and machines alike could be the "means of producing a useful result," but descriptions of the former need not be restricted to any specific arrangements of the latter. On the contrary, there are processes that could be performed "in many modes and by the use of many forms of apparatus." For this reason, Bradley reasoned, inventors are required to disclose at least one "particular mode, or some apparatus" that enables their process, but they are by no means required to disclose them all. ${ }^{62}$

Cochrane and Tilghman were central to one of the most prominent textbooks of the late nineteenth century, William Robinson's treatise The Law of Patents for Useful Inventions (1890). Robinson used the terms "art," "process," and "mode of treatment" interchangeably in reference to "an act or a series of acts performed by some physical agent upon some physical object" in a way that produces "some change either of character or of condition" on the object

56. Transcript of record, Cochrane v. Deener, 94 U.S. 780 (1876).

57. Argument of Howard C. Cady for defendants, Cochrane v. Deener, 11-13.

58. Cochrane v. Deener, 788.

59. Ibid.

60. Tilghman v. Proctor, 102 U.S. 707 (1881).

61. Ibid., 728

62. Ibid. 
being manipulated. ${ }^{63}$ A process, according to Robinson, is simultaneously abstract and concrete. It is abstract in the sense that a person can understand it without the need to contemplate the specific instruments that perform it. It is concrete in that it "consists in the application of physical force through physical agents to physical objects." 64 This meant that processes, though comprehensible in the abstract, became "apparent to the senses only in connection with some tangible instrument or object." 65

This physicality was essential to Robinson's conception of a process. He explained that every invention "must accomplish some change in the character or condition of material objects" and that any art "must produce physical effects." ${ }_{66}$ As a result, a "plan or theory of action" that produces no physical results is never an art or process. Robinson conceded that this plan may constitute an invention but, regardless of what important ends this invention may accomplish, it "lies outside the domain of the industrial arts." 67 This meant that copyrights, not patents, were the appropriate protections for it. ${ }^{68}$

These conceptions of a process were not confined to academic treatises and the nation's highest court. In the early twentieth century, the assistant commissioner of patents, Cornelius Billings, brought Robinson's understanding of a process to the Patent Office. ${ }^{69}$ Billings's understanding of patent law stemmed from a combination of on-the-job training and formal legal education. In 1907, he heard an appeal related to an invention in calligraphy. An inventor named Thomas Meinhardt had submitted a patent application for what he called a "system for spacing free-hand letters." 70 Meinhardt had devised a system that would allow calligraphers to standardize the proportions of their letters and kerning. This system consisted of a series of guiding lines that the calligrapher could adjust and use as a visual aid from one letter to the next. The examiners at the Patent Office had rejected Meinhardt's application on the grounds that a process to determine proportions and lengths was ineligible for patent protection, and Meinhardt had filed an appeal.

Firmly grounded on Robinson's views, Billings affirmed the rejection of Meinhardt's patent application. ${ }^{71}$ The assistant commissioner explained that there were two classes of processes allowable by patent law. First are those that "involve a chemical or other elemental action." This corresponded to processes such as chemical reactions, which, in Robinson's framework, produced a change in character on a tangible substance. Second are those processes "which are of a mechanical nature" and "are not absolutely dependent on a machine." ${ }^{72}$ Cochrane's flour refinement process was perhaps the best-known process of this kind. Meinhardt's process did not belong to either category, so it was ineligible for a patent.

63. Robinson, The Law of Patents for Useful Inventions, 230.

64. Ibid, 231.

65. Ibid.

66. Ibid., 249.

67. Ibid., 250.

68. Ibid.

69. See Westinghouse v. Boyden Power Brake, 170 U.S. 537 (1898); Expanded Metal v. Bradford, 214 U.S. 366 (1909).

70. Ex Parte Meinhardt, 129 O.G. 2503.

71. He drew this reading from In Re Weston (C.T. 1901 290; O.G. 1786), Court of Appeals of the District of Columbia.

72. Ex Parte Meinhardt, 129 O.G. 2503. 
Courts in the 1920s and 1930s cited these conceptions of a process to justify patent invalidations. ${ }^{73}$ They treated the nineteenth-century cases as a precedent for the reasoning that patent-eligible processes must exhibit some kind of materiality; the tangibility ascribable to patentable devices had a counterpart in patentable processes. Within this framework, when process patents reached the courts through infringement suits, their specifications played the vital role of demonstrating to the judges that the processes at hand were tied to tangible transformations. This requirement for materiality would come under intense scrutiny with legal challenges to software patenting in the 1960s onward. ${ }^{74}$

By the time Halliburton and Walker first went to court in the 1940s, these nineteenthcentury cases provided sufficient precedent for judges to develop a near-total ban on processes that involved mathematical computations. Walker lost one of his patents at the District Court for the Southern District of California. Judge Hall invalidated patent number 2,209,944 (hereon referred to as patent '944), titled "Method of Measuring Location of Obstructions in Deep Wells." Its first claim, partially reproduced below, illustrates the blend of mechanical and computational steps that the patent covered:

The method of accurately determining the unknown location of an obstruction in a well ... which consists in

[1] creating a pressure impulse in the annular space between the tubing and casing of the well,

[2] registering the echoes from the tubing collars and from said obstruction, and

[3] counting the tubing collar echoes occurring between the creation of the pressure impulse and the echo from the unknown obstruction, to determine the location of the unknown obstruction. ${ }^{75}$

The steps highlighted above include the use of the Depthograph to generate echoes and create a printout, but they also include steps that users must perform on their own: counting the spikes in a graph that denote echoes caused by the pipe's tubing collars and using this information to determine the location of the obstruction. In other words, this single claim blends the use of steps and devices with a distinct tangibility-the Depthograph machine, its printouts, and the generation of sound within the pipe-with a computation that may very well take place in the user's mind, namely, counting spikes on a graph. Later claims are similar, outlining actions such as "observing the lapse of time," "computing the distance to the unknown obstruction," and "comparing the elapsed time."76

Hall ruled that this language rendered the patent invalid. Halliburton had not formally introduced this reasoning to the court, and no records suggest that Walker had faced any pushback at the Patent Office regarding his use of these terms. Still, Hall invalidated the patent on the grounds that its novelty "consists only in the performance of mental steps such as

73. See, for example, Holland Furniture v. Perkins Glue, 277 U.S. 245 (1928); American Tri-Ergon v. Paramount Publix, 4 F. Supp. 462 (1933); National Popsicle Corporation v. Harvey, 6 F. Supp. 784 (1934).

74. Con Díaz, Software Rights.

75. Walker, Method of measuring location of obstructions in deep wells, 6 (formatting and numbering added by the author).

76. Ibid., 6-7 (emphasis added). 
'counting,' 'observing,' 'computing,' and 'comparing.,"'77 Without citing any immediate precedent, but grounding his decision in the body of nineteenth-century law outlined earlier, he concluded that each of the claims defines "methods which do not involve invention and are unpatentable."78

This reasoning brought novelty into Hall's assessment of patent eligibility. ${ }^{79} \mathrm{He}$ thought that the problem was not that the patented process involved mental (and therefore intangible) steps such as counting, observing, computing, or comparing. It was, instead, that the novelty of the patents consisted of performing those actions. His ruling implicitly assumed that the steps in a process can be neatly divided into novel steps and those that are not new, and that the inventor must demonstrate that at least some of the materiality of the process resides in the novel steps. If a process differs from the prior art only in steps that do not qualify for patent protection, then it does not constitute patentable invention. In short, Hall implied that a process is patent eligible if, and only if, its novelty lies in its tangible steps.

Hall's decision to uphold Walker's other two patents underscores the inseparability among processes, materiality, and patent eligibility that he advanced. He upheld patent 2,156,519 (hereon '519) without a problem. This apparatus patent was titled "Means for Measuring the Location of Obstructions in Deep Wells." ${ }^{80}$ It covered the same device as the one in the '944 patent, and the two patents even shared the image in Figure 2. Patent '519 also used words such as "counting" and "determining" in its claims. However, unlike its method-based counterpart, the '944 patent embedded them in clauses that described distinctly material inventions: an "apparatus for determining the location of an obstruction" and a "means associated with [a] pressure responsive device for measuring the frequency of ... tubing collar echoes and for counting the same and for measuring [a] lapse of time." 81

Hall also upheld Walker's third patent, a reissued patent numbered Re. 21,383 (hereon '383). ${ }^{82}$ Like the '944 patent, this one also covered a computation-intensive method that relied on the apparatus protected in patent '519. It was titled "Method of Determining Fluid Density, Fluid Pressure, and the Production Capacity of Oil Wells," and it too used the terms "computing," "comparing," and "determining" in its claims. Like the apparatus patent, this one also embedded these terms in broader clauses that involved tangible components. For instance, one claim included the step of "computing the unknown pressure ... by adding to gas pressure upon the fluid surface ... the effect in pressure of the fluid column." ${ }^{83}$ Rather than disclosing tangible components of the invention, phrases like these tied mental steps to the tangible changes in their surroundings such as changes in fluid surfaces and additions of gas pressure. To Hall, this was enough to demonstrate that the novelty of the method (the computations themselves) were not purely mental in nature; no human mind could change air pressures without somehow manipulating air.

77. Findings of Fact and Conclusions of Law, April 22, 1943, ToR, 30.

78. Ibid., ToR, 32 .

79. This paragraph is based on Findings of Fact and Conclusions of Law, ToR, 27-31.

80. Walker, Means for measuring the location of obstructions in deep wells.

81. Ibid., 6.

82. Walker, Method of determining fluid density, fluid pressure, and the production capacity of oil wells.

83. Ibid., 6. 
The judge's focus on the literal language of the patent was not an unusual move. Since the mid-nineteenth century, the textual interpretation of claims has been the primary means for courts to grapple with the substance of an invention. ${ }^{84}$ As other scholars have shown, the representations of an invention-first through patent models and later exclusively through textual means-serve as stand-ins for the invention at the Patent Office and the courts. By midcentury, the study of patent texts had replaced actual mechanical examination in assessments of patent eligibility and infringement. Along the way, the primary object of legal scrutiny in these legal proceedings became what other scholars have called a "semantic artefact," an "assemblage of textual, material, and oral resources." ${ }^{85}$ In this framework, wherein the text of the patent reigns supreme as a proxy for the invention at which it is aimed, it was not controversial to focus on the claims' wording to assess the nature of an invention.

Hall's reasoning quickly became part of the Patent Office's repertoire of rationales for the rejection of process patent applications. In 1943, the Patent Office Board of Appeals issued a decision called Ex Parte Read on the patent eligibility of a method to determine the speed of an automobile by arranging two circular mathematical scales. ${ }^{86}$ Although the scales themselves were tangible objects, the board rejected this method on the grounds that it failed "to define a true method," because it amounted to "correlating the reading of one scale with reading on the other." This was a "purely mental act" that fails to qualify as a "true manipulative step." 87 A few months later, the same board issued a similar decision in Ex Parte Toth and Nutter. ${ }^{88}$ The patent application at hand was an improvement on one of the patents that Hall had upheld, and it was directed at the measurement of the air pressure inside an oil well. ${ }^{89}$ Without addressing the validity of Walker's patent, the board followed Hall's ruling and explained that steps such as determining the well pressure are not patentable processes on their own, as they "are purely mental" and do not qualify as an art. ${ }^{90}$ Along the way, Halliburton gained new language with which to defend itself from Walker's accusations of infringement.

Back at the federal courts, Walker's loss of a single patent was not enough to allow Halliburton's continued unrestricted use of the Echo-Meter, so the firm appealed Hall's decision to the Court of Appeals for the Ninth Circuit. ${ }^{91}$ Once again Graham and Babcock, Halliburton's attorneys, delivered a full slate of defenses against Walker's claims of infringement. Their most important aim was to invalidate the '383 patent, Walker's remaining method patent, by adopting Hall's language for the invalidation of the '944 patent. In particular, the lawyers argued that Hall had erred in not finding that the novelty in the ' 383 patent "resides in the mental or mathematical steps or 'dividing,' 'comparing,' 'determining,' etc. which do not constitute patentable subject matter." 92 Hinting at the industrial impact of patents that covered

84. Pottage and Sherman, Figures of Invention; Biagioli, "Patent Republic."

85. Pottage and Sherman, Figures of Invention, 129

86. Ex Parte Read, 123 U.S.P.Q. 446 (1943).

87. Ibid., 446.

88. Ex Parte Toth and Nutter, 63 U.S.P.Q. 131 (1944)

89. This was related to Walker, Method of determining fluid density, fluid pressure, and the production capacity of oil wells.

90. Ex Parte Toth and Nutter, 131.

91. Statement of Points on Which Defendant-Appellant Intends to Rely on Appeal, ToR, 39-42.

92. Ibid., 42 . 
mental steps, they told the Ninth Circuit that Walker was "attempting to assert a broad and dominating monopoly unsupported by any alleged invention" in the two remaining patents. ${ }^{93}$

Judge William Healey at the Ninth Circuit accepted and expanded Hall's textual examination of the nature of the invention and his nineteenth-century conception of a process. $\mathrm{He}$ agreed with Hall's invalidation of the '944 patent, highlighting its use of terms that denoted the presence of mental steps-from determining and registering, to counting and computing. ${ }^{94}$ The method, according to Healey, consisted simply of plugging in three quantities into a "simple equation and from them determining or computing an unknown." Citing the nineteenth-century cases and some of their more recent applications, Healey noted that "these mental steps, even if novel, are not patentable." 95 The issue here was that '944 was "purely a method patent" and that it did not claim any apparatus. Because "anybody with a rudimentary knowledge of arithmetic" would be able to perform these computations, patent protection would give Walker "a monopoly much broader than would the patentee of a particular apparatus."

To Healey, a strong ban on processes such as Walker's was essential to ensure that process patent rights were not improperly broad. He did not doubt the validity of patent ' 519 (for the apparatus), but he did construe Walker's other process patent as another attempt to secure an improperly broad monopoly over mental processes. In fact, he explained that everything he had concluded about the '944 patent also applied to '383 (for Walker's method of computing fluid densities). Even if Walker's process "may have elements of novelty," it did not constitute a patentable invention. ${ }^{96}$ Walker's attorneys had argued forcefully that the presence of the words that troubled Hall and Healey did not mean that his patent was directed at pure arithmetic, but Healey would have none of it. Unlike Hall, he did not care that the computations were tied to transformations in the tangible environments wherein the measurements had taken place. Instead, what mattered to him was that patent protections for mental stepsregardless of their relationships with tangible things-would grant improperly broad monopoly power.

\section{Long-Lasting Impact}

Over the next few years, Walker lost his third and final patent ('519) and Hall and Healey's reasoning became standard lines of thought when dealing with process patents. Walker's final loss occurred in 1946, at the Supreme Court. ${ }^{97}$ Patent '519 was directed at a machine, not a process, so the court's rationale in this final rejection did not rely on the same arguments as the lower courts. Instead, the Supreme Court simply found, in alignment with Halliburton's complaints, that Walker had failed to provide the "full, clear, concise, and exact" description of the invention as required by law. ${ }^{98}$ In doing so, the court left unchanged the rationales on the

93. Ibid., 41.

94. This paragraph is drawn from Halliburton v. Walker, 146 F.2d 817, 821.

95. See also Lee v. Walker, 61 F.2d 58 (9th Circuit, 1932).

96. This paragraph is based on Lee v. Walker, 824.

97. Halliburton v. Walker, 329 U.S. 1 (1946).

98. Ibid. 
patent eligibility of processes that the Hall and Healy had developed based on their reading of the nineteenth-century case law. As far as the Supreme Court's opinion was concerned, there was no issue with the identification of processes as manipulations of tangible substances.

No records suggest that Walker's company entered any new significant markets after the defeat at the Supreme Court or that he patented any devices after the mid-1940s. Instead, Halliburton's victory allowed the firm to add well depth measurement, obstruction detection, and pressure measurements to its already growing repertoire of services. The firm continued to list the Echo-Meter among its offerings well into the 1950s. ${ }^{99}$

However, Halliburton v. Walker had a much broader impact beyond the oil industry, because Hall's and Healey's opinions became examination standards at the Patent Office and the courts. Their clearest rearticulation occurred in 1951, at the Court of Customs and Patent Appeals-CCPA, the court, now defunct, that heard appeals of the Patent Office's final rejections. Armand Abrams, from the Socony Vacuum Oil Company in Texas, had approached the court in hopes of reversing a rejection on patent-eligibility grounds for his patent, "Improvements in Petroleum Prospecting Method." His method consisted of a technique to detect natural gases by measuring their flow rates into a metal cylinder introduced into the ground. Following Healey's rationale, the examiner at the Patent Office rejected the application on the grounds that it relied on the words "calculating," "comparing," "computing," and "determining" to claim the invention. The CCPA sided with the Patent Office, and its opinion implied that there are three kinds of processes: First are those in which all steps are computational. These are never patent eligible. Second are processes that involve computational and material steps, and in which the invention's novelty lies in the computational ones. These, too, are ineligible for patents. Third are processes that involve both kinds of steps, and in which novelty lies on its material ones. These are the only ones eligible for patents.

During the 1960s, this kind of reasoning provided the groundwork for early guidelines regarding the patent eligibility of inventions involving computer programs. ${ }^{100}$ In 1968 - on the eve of the modern software industry's birth—the Patent Office issued its first-ever guidelines on the matter. The office noted that "a process or method is directed to patentable subject matter only if it is performed on physical materials and produces some appreciable change in their character or condition." 101 At the same time, according to the guidelines, a "computer programming process" could take two forms. The first, which was not eligible for patent protection, "produces no more than a numerical, statistical, or other informational result." The second, and only one that may be "part of a patentable invention," is a programming process that "is combined in an unobvious manner with physical steps [such as] the knitting of a pattern or the shaping of metal."

Starting in the late 1960s, the continued arrival of software patents at the courts prompted judges and lawyers to question whether the mere presence of words denoting mental steps was enough to bar an invention's patent eligibility. ${ }^{102}$ Inventors could present computer programs

99. See, for instance, McCoy, Automatic echo meter.

100. This paragraph is based on Con Díaz, Software Rights.

101. The quotes in this paragraph are drawn from "Examination of Patent Applications on Computer Programs."

102. This paragraph is based on Con Díaz, Software Rights. 
in the form of hardware, software, or a hybrid of the two, so courts found it difficult to reduce the patent eligibility of a computational process to the specific verbs to describe their operation. It was not until the 1970s, when a focus on characterizing software as an invention and formalizing patent law's relationships with algorithms intensified, that these issues would emerge again in full force. For the rest of the century, it would be up to firms in the computing industry, not oil services, to solve the thorny conceptual problems that Halliburton v. Walker had brought into midcentury American patent law.

\section{Conclusion}

Short-term industrial goals can have a long-lasting impact on the conceptual underpinnings of patent law. The patent-eligibility standards that courts developed during Halliburton $v$. Walker were so stringent that even the mere presence of certain words became enough to invalidate a patent. This infused U.S. patent law with a strict duality between tangibility and intangibility-that is, with the assumption that an invention's components can be sorted neatly into these two categories. However, this duality was a discursively enforced legal artifice born from courts' strict reliance on the patent specification to identify the characteristics of an invention and assess their patent eligibility. This transformed the materiality of an invention into a quality to be determined purely on a textual basis, by examining the specific words that inventors used to describe their creations.

This overly legalistic view of materiality was born from the long history of patenting processes in the nineteenth century, but it entered the canon of modern patent law thanks to the Depression-era race to enter the market for oil well depth measurement services. In the late 1930s, the problem of detecting oil pools and well obstructions had become so pressing that it drew established companies and independent inventors alike. Rather than working in isolation, these developers visited one another and tested prototypes at one another's facilities. Always careful to reveal only the general principles that informed their work, and not the specific implementations that they were developing, these inventors were collaborative competitors. They worked at the core of a nascent oil services industry dependent on techniques for the study and measurement of sound waves using electronic components such as resonators and microphones.

Halliburton's strategic takedown of Walker's patents facilitated the reemergence of computation and materiality as interrelated concepts in American patent law, but Halliburton itself was not entirely responsible for courts' handling of materiality and computation. Halliburton and Walker had both been drawn to the industry rumor that Union Oil would soon gain an important competitive advantage in oil well analysis. Halliburton responded first through a corporate acquisition, but it was Walker, an entrepreneurially oriented newcomer, who initiated the legal conflicts that would eventually cause him to lose his patents. Of the arguments that courts used to invalidate these patents, only the Supreme Court's-on Walker's failure to disclose his invention in an appropriate manner-had been introduced by Halliburton. The patent-eligibility argument that the lower courts used were born from the district court's effort to reconstruct a framework for the patent eligibility of processes from the Supreme Court's nineteenth-century opinions on the matter. 
The district court's opinion placed extraordinary emphasis on the language of the patent's claims. By focusing on words that denoted mental steps, the court invalidated Walker's first process patent on the grounds that it was not eligible for patent protection. To protect and increase its market power, Halliburton weaponized the district court's reasoning against Walker at the appellate level. The appeals court adopted and expanded this reasoning, invalidating Walker's second patent and suggesting that cursory transformations of tangible matter were not sufficient to bypass the mental steps doctrine that the lower court had articulated. This made characterizing the relationships between computations and materiality a central problem in the legal delineation of processes as a category of invention. Walker ultimately lost his battle against Halliburton, but their battle had repercussions that transcended the Southern California oil rigs where it began: For the next few decades, as the computing industry started to grapple with its own patent wars, Halliburton v. Walker would continue to echo in courtrooms across the United States.

GERARDo Con Díaz is associate professor of Science and Technology Studies at the University of California, Davis. He is a National Fellow at the Hoover Institution (Stanford University) and the editor-in-chief of the Annals of the History of Computing. His first book, Software Rights: How Patent Law Transformed Software Development in America, was published by Yale University Press in 2019. Contact information: Department of Science and Technology Studies, University of California, Davis, Social Science and Humanities 1246, 1 Shields Avenue, Davis, CA, 95616. E-mail: condiaz@ucdavis.edu.

\section{Acknowledgement}

The author is grateful to the Alfred P. Sloan Foundation, the Department of Science and Technology Studies at the University of California, Davis, the Hoover Institution, and the Center for Intellectual Property x Innovation Policy (C-IP2) at George Mason University for their financial and intellectual support. This article was developed through C-IP2's Thomas Edison Innovation Fellowship, and it benefited greatly from the feedback provided by Adam Mossoff and the fellowship's senior commentators: John Duffy, Ted Sichelman, Jonathan Barnett, Jay Aronson, and Eric Claeys.

Bibliography of Work Cited

\section{Books}

Andreano, Ralph, Arnold Daum, and Gilbert Klose. The American Petroleum Industry: The Age of Energy, 1899-1959. Evanston: Northwestern University Press, 1963.

Atabaki, Tourak, Elisabetta Bini, and Kaveh Ehsani, eds. Working for Oil: Comparative Social Histories of Labor in the Global Oil Economy. Basingstoke, UK: Palgrave Macmillan, 2018.

Beauchamp, Christopher. Invented by Law: Alexander Graham Bell and the Patent That Changed America. Cambridge: Harvard University Press, 2015.

Bottomley, Sean. The British Patent System During the Industrial Revolution, 1700-1852. New York: Cambridge University Press, 2014.

Briody, Dan. The Halliburton Agenda: The Politics of Oil and Money. New York: Wiley, 2005. 
Con Díaz, Gerardo. Software Rights: How Patent Law Transformed Software Development in America. New Haven: Yale University Press, 2019.

Fisk, Catherine. Working Knowledge: Employee Innovation and the Rise of Corporate Intellectual Property, 1800-1930. Durham: University of North Carolina Press, 2009.

Gabriel, Joseph. Medical Monopoly: Intellectual Property Rights and the Origins of the Modern Pharmaceutical Industry. Chicago: Chicago University Press, 2014.

Greene, Jeremy. Generic: The Unbranding of Modern Medicine. Baltimore: Johns Hopkins University Press, 2014.

Holt, Francis Ludlow. Reports of Cases Ruled and Determined at Nisi Prius in the Court of Common Pleas. London: J. Butterworth \& Son, 1818.

Khan, Zorina. The Democratization of Invention: Patents and Copyrights in American Economic Development, 1790-1920. New York: Cambridge University Press, 2009.

Mitchell, Timothy. Carbon Democracy: Political Power in the Age of Oil. London: Verso, 2011.

Parthasarathy, Shobita. Patent Politics: Life Forms, Markets, and the Public Interest in the United States and Europe. Chicago: University of Chicago Press, 2017.

Pottage, Alain, and Brad Sherman, Figures of Invention: A History of Modern Patent Law. New York: Oxford University Press, 2010.

Priest, Tyler. The Offshore Imperative: Shell Oil's Search for Petroleum in Postwar America. College Station: Texas A\&M University Press, 2007.

Robinson, William. The Law of Patents for Useful Inventions. Vol. 1. Boston: Little, Brown, and Company, 1890.

Sabin, Paul. Crude Politics: The California Oil Market, 1900-1940. Berkeley: University of California Press, 2005.

Usselman, Steven. Regulating Railroad Innovation: Business, Technology, and Politics in America, 1840-1920. New York: Cambridge University Press, 2002.

\section{Articles, Chapters in Books, Research Papers, and Theses}

Biagioli, Mario. "Patent Republic: Representing Inventions, Constructing Rights and Authors." Social Research 73, no. 4 (Winter 2006): 1129-1172.

Con Díaz, Gerardo. "Encoding Music: Perforated Paper, Copyright Law, and the Legibility of Code, 18801908." Case Western Reserve Law Review (forthcoming).

"Examination of Patent Applications on Computer Programs." Federal Register 33 (October 22, 1968): 15,609-15,610.

Kevles, Daniel. "Ananda Chakrabarty Wins a Patent: Biotechnology, Law, and Society." Historical Studies of the Physical and Biological Sciences 25, no. 1 (1993): 111-135.

Mossoff, Adam. "O’Reilly v. Morse.” George Mason Law \& Economics Research Paper No. 14-22, August 18, 2014. https://ssrn.com/abstract=2448363.

Rankin, William. "The 'Person Skilled in the Art' Is Really Quite Conventional: US Patent Drawings and the Persona of the Inventor, 1870-2005." In Making and Unmaking Intellectual Property: Creative Production in Legal and Cultural Perspective, edited by Mario Biagioli, Peter Jaszi, and Martha Woodmansee, 55-78. Chicago: University of Chicago Press, 2011.

Rodd, Charles. "The Application of Fluid Level Measurements to Oil Wells in Kansas." Professional degree thesis, School of Mines and Metallurgy of the University of Missouri, 1940.

Samuelson, Pamela. "The Story of Baker v. Selden: Sharpening Distinctions Between Authorship and Invention." In Intellectual Property Stories, edited by Jane C. Ginsburg and Rochelle Cooper Dreyfuss, 159-193. New York: Foundation Press, 2005. 
Williamson, Harold, Ralph Andreano, and Carmen Menezes, “The American Petroleum Industry.” In Output, Employment, and Productivity in the United States After 1800, edited by Dorothy Brady, 349-404. Cambridge, MA: National Bureau of Economic Research, 1966.

\section{Patents}

Batcheller, Birney. Apparatus for locating obstructions in tubes. US Patent 602,422, filed September 28, 1897, and issued April 19, 1898.

Bouton, Edgar, and Cranford Walker. Variable-voltage-control system. US Patent 1,732,712, filed February 6, 1922, and issued October 22, 1929.

De Camp, Ray, Milton Baruch, and Cranford Walker. Automatic stopping elevator control system. US Patent 1,895,065, filed November 16, 1925, and issued January 24, 1933.

Jakosky, John. Method and apparatus for continuous exploration of bore holes. US Patent 2,181,601, filed December 21, 1938, and issued November 28, 1939.

Lehr, Paul, and Harold T. Wyatt. Method and apparatus for measuring well depths. US Patent 2,047,974, filed November 1, 1933, and issued July 21, 1936.

Lyons, Daniel, and Walker Cranford. Elevator door operator. US Patent 1,823,862, filed August 16, 1930, and issued September 22, 1931.

McCoy, James. Automatic echo meter. US Patent 4,934,186, filed September 29, 1987, and issued June 19, 1990.

Walker, Cranford. Valve operating means. US Patent 2,038,252, filed May 31, 1935, and issued April 21, 1936.

- Means for measuring the location of obstructions in deep wells. US Patent 2,156,519, filed September 7, 1937, and issued May 2, 1939.

- Method of determining fluid density, fluid pressure, and the production capacity of oil wells. US Patent Re 21,383, originally issued as 2,161,711, filed October 26, 1937, and reissued March $5,1940$.

- Method of measuring location of obstructions in deep wells. US Patent 2,209,944, filed September 7, 1937, and issued July 30, 1940.

\section{Archives and Court Opinions}

Note: Transcripts of record for the Supreme Court opinions listed below are available at the Supreme Court Repository, Yale University Law Library, and through legal databases such as The Making of Modern Law: U.S. Supreme Court Records and Briefs, 1831-1978.

American Tri-Ergon v. Paramount Publix, 4 F. Supp. 462 (1933).

Cochrane v. Deener, 94 U.S. 780 (1876).

Burr v. Duryee, 68 U.S. 531 (1864).

Corning v. Burden, 56 U.S. 252 (1853).

Expanded Metal v. Bradford, 214 U.S. 366 (1909).

Ex Parte Meinhardt, 129 O.G. 2503.

Ex Parte Read, 123 U.S.P.Q. 446 (1943)

Ex Parte Toth and Nutter, 63 U.S.P.Q. 131 (1944).

Graver Tank v. Linde Air Products, 339 U.S. 605 (1950).

Halliburton v. Walker, 329 U.S. 1 (1946).

Holland Furniture v. Perkins Glue, 277 U.S. 245 (1928).

In Re Weston (C.T. 1901 290; O.G. 1786). 
Lee v. Walker, 61 F.2d 58 (9th Circuit, 1932).

National Popsicle Corporation v. Harvey, 6 F. Supp. 784 (1934).

Peirson M. Hall Papers, Huntington Library, San Marino, California.

Tilghman v. Proctor, 102 U.S. 707 (1881).

Westinghouse v. Boyden Power Brake, 170 U.S. 537 (1898).

Cite this article: Con Díaz, Gerardo. "Patent Law and the Materiality of Inventions in the California Oil Industry: The Story of Halliburton v. Walker, 1935-1946.” Enterprise \& Society 24, no. 1 (2023): 174-196. 